\title{
Surface and subsurface flow effect on permanent gully formation and upland erosion near Lake Tana in the northern highlands of Ethiopia
}

\author{
T. Y. Tebebu ${ }^{1,3}$, A. Z. Abiy ${ }^{3}$, A. D. Zegeye ${ }^{3,4}$, H. E. Dahlke ${ }^{1}$, Z. M. Easton ${ }^{1}$, S. A. Tilahun ${ }^{1,2}$, A. S. Collick ${ }^{1,2}$, \\ S. Kidnau ${ }^{4,5}$, S. Moges ${ }^{6}$, F. Dadgari ${ }^{5}$, and T. S. Steenhuis ${ }^{1,2,3}$ \\ ${ }^{1}$ Biological and Environmental Engineering, Cornell University, Ithaca, NY USA \\ ${ }^{2}$ School of Civil and Water Resources Engineering Bahir Dar University Bahir Dar, Ethiopia \\ ${ }^{3}$ Integrated Watershed Management and Hydrology Master Program, Cornell University at Bahir Dar, Ethiopia \\ ${ }^{4}$ Amhara Regional Agricultural Research Institute (ARARI) Addet Ethiopia \\ ${ }^{5}$ SWISHA, Bahir Dar, Ethiopia \\ ${ }^{6}$ Engineering Faculty Addis Ababa University, Addis Ababa, Ethiopia
}

Received: 9 July 2010 - Published in Hydrol. Earth Syst. Sci. Discuss.: 3 August 2010

Revised: 2 November 2010 - Accepted: 3 November 2010 - Published: 5 November 2010

\begin{abstract}
Gully formation in the Ethiopian Highlands has been identified as a major source of sediment in water bodies, and results in sever land degradation. Loss of soil from gully erosion reduces agricultural productivity and grazing land availability, and is one of the major causes of reservoir siltation in the Nile Basin. This study was conducted in the 523 ha Debre-Mawi watershed south of Bahir Dar, Ethiopia, where gullies are actively forming in the landscape. Historic gully development in a section of the Debre-Mawi watershed was estimated with semi structured farmer interviews, remotely sensed imagery, and measurements of current gully volumes. Gully formation was assessed by instrumenting the gully and surrounding area to measure water table levels and soil physical properties. Gully formation began in the late 1980's following the removal of indigenous vegetation, leading to an increase in surface and subsurface runoff from the hillsides. A comparison of the gully area, estimated from a $0.58 \mathrm{~m}$ resolution QuickBird image, with the current gully area mapped with a GPS, indicated that the total eroded area of the gully increased from 0.65 ha in 2005 to 1.0 ha in 2007 and 1.43 ha in 2008 . The gully erosion rate, calculated from cross-sectional transect measurements, between 2007 and 2008 was $530 \mathrm{tha}^{-1} \mathrm{yr}^{-1}$ in the 17.4 ha area contributing to the gully, equivalent to over $4 \mathrm{~cm}$ soil loss over the contributing area. As a comparison, we also measured rill
\end{abstract}

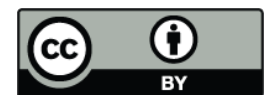

Correspondence to: Z. M. Easton (zme2@cornell.edu) and interrill erosion rates in a nearby section of the watershed, gully erosion rates were approximately 20 times the measured rill and interrill rates. Depths to the water table measured with piezometers showed that in the actively eroding sections of the gully the water table was above the gully bottom and, in stable gully sections the water table was below the gully bottom during the rainy season. The elevated water table appears to facilitate the slumping of gully walls, which causes the gully to widen and to migrate up the hillside.

\section{Introduction}

Soil erosion is one of the most challenging global environmental problems. Loss of soil has both on-site effects, such as loss of soil fertility and lowered water holding capacity, and off-site effects, such as siltation of reservoirs and lakes (Tamene and Vlek, 2007). Unfortunately, erosion is often far more severe in developing countries than in industrialized countries, often a result of the lack of financial, technical, and institutional capacity (Tamene and Vlek, 2008). In the Ethiopian Highlands, erosion has increasingly received greater attention since the 1980's following the development of the Soil Conservation Research Program (Hurni, 1988; Moges and Holden, 2008). Since 1985 the government of Ethiopia has run an ambitious soil and water conservation (SWC) program supported by donors and nongovernmental organizations and backed by the largest food-for-work

Published by Copernicus Publications on behalf of the European Geosciences Union. 
program in Africa (Hoben, 1995). Today the Productive Safety Net Program continues to implement many SWC measures in places where food security is an issue. More recently, researchers from Switzerland and Belgium in cooperation with Ethiopian researchers have made great advances in both understanding and control of upland erosion (Beshah, 2003; Bewket and Sterk, 2005; Herweg and Ludi, 1999; Hurni et al., 2005; Nyssen et al., 2004; Shiferaw and Holden, 1998). However, gully erosion is still, at best, poorly understood, and little has been done in practice to control gully erosion.

While mechanisms for upland erosion are relatively well understood and acceptable soil loss rates have been established (Haile et al., 2006), the processes controlling gully erosion are poorly understood (Nyssen et al., 2006). Gully erosion is defined as the erosion process whereby runoff water accumulates in narrow channels and removes considerable amount of soil from this narrow channel over a short time period. A working definition of gullies in agricultural land is defined in terms of channels too deep to easily pass over with ordinary farm tillage equipment, typically anything deeper than $0.5 \mathrm{~m}$ (Poesen et al., 2003; Soil Science Society of America, 2010). Gullies can be active (actively eroding) or inactive (stabilized). An active gully (Poesen et al., 2002, 2003) can occur where the erosion is actively moving up in the landscape by head cut migration. Stabilized gullies have ceased widening and head cutting, and sometimes begin to fill with sediment.

While gully erosion is not a new phenomenon by any means, its importance has gained more attention recently. For instance, Carnicelli et al. (2009) examined gully formation since the late Holocene period in the Ethiopian Highlands and found that besides tectonic events, that gully formation is triggered by an increase in the stream transport capacity at the start of wet periods, while gully stabilization and filling occurs during transitions towards drier climate phases where there is reduced water transport capacity. Several episodes of gully formation, stabilization, and re-filling have occurred prior to the spread of modern agriculture in the Highlands. Following the spread of agriculture to the Highlands, gully formation was found to be driven primarily by anthropogenic factors. For instance, Nyssen et al. (2006) found that gully development in the Highlands was related to a land use/land cover change such as planting of eucalyptus trees, cultivation of new land, or by the degradation of the vegetation cover on steep slopes. Yet it is still not clear if gully formation results directly from land management practices (tillage, crop type) or from a change in the hydrology of the landscape due to land management (e.g., higher water tables, lower evapotranspiration), or some combination of the two.

Two cases of the interaction between gully formation and hydrology can be distinguished; one in which gully formation affects the hydrology and the other where the hydrology affects the gully erosion. The main effect of gully formation on the hydrology is that gully incision lowers the ground water levels by providing a shorter drainage path to the outlet for the same difference in elevation (Hagberg, 1997; Poesen et al., 2003). Hydrological controls on gully formation are generally assumed to be dominated by the amount of surface runoff (Poesen et al., 2003; Carey, 2006; Mogis and Holden, 2009). The reasoning is that the smaller the stream power the smaller the gully erosion (Nyssen et al., 2006). Therefore, installation of upland soil and water conservation practices that reduce runoff (and increase infiltration) are expected to decrease gully formation (Nyssen et al., 2006; Wilson et al., 2008) but, as shown in the results and discussion section of this study the increasing infiltration might increase the development of gullies. A review of the role of subsurface flow on gully formation has recently been published by Fox and Wilson (2010), however, results are mainly based on laboratory experiments. Limited information exists on the effect of the subsurface flow processes on gully erosion under field conditions (Fox et al., 2007). In one field study in south eastern Nigeria, gullies were found in the discharge areas of groundwater systems, and were activated during the peak recharge times of the rainy season because high pore-water pressures reduced the effective strength of the unconsolidated materials along the seepage faces (Okagbue and Uma, 1987). The seepage forces caused by the hydraulic gradient in the gully walls produce piping and tunneling that undermine the gully walls and activate their retreat (Fox et al., 2007).

The effect of subsurface flow process on gully formation in the Ethiopian Highlands has not received sufficient attention. Determination of which hydrological process (subsurface or surface) is the dominant cause of erosion, or the degree to which they are interrelated, is important for recommending effective erosion control management practices. In the research reported here we explored the interaction of hydrological factors on gully formation, and compared gully erosion rates to better understood rill and interrill erosion rates in the Debre-Mawi watershed.

\section{Material and methods}

The study was performed in the 523 ha Debre-Mawi watershed located between $11^{\circ} 20^{\prime} 13^{\prime \prime}$ and $11^{\circ} 21^{\prime} 58^{\prime \prime}$ North and $37^{\circ} 24^{\prime} 07^{\prime \prime}$ and $37^{\circ} 25^{\prime} 55^{\prime \prime}$ East, $30 \mathrm{~km}$ south of Lake Tana, Bahir Dar, Ethiopia (Fig. 1). Elevations range from 1950 to $2309 \mathrm{~m}$ above sea level (a.s.1.) and slope varies from 6$35 \%$. Average rainfall, falling mainly from June to September, is $1240 \mathrm{~mm}$. Land use consists of rain fed agriculture in a mixed farming system with scattered indigenous tree species, including Cordia sp. The soils in the landscape are dominated by vertisols.

Two sub-watersheds were selected for closer study within the 523 ha Debre-Mawi watershed (Fig. 1). These watersheds, while historically agricultural were not under active tillage or agricultural management from 1974-1987 due to 


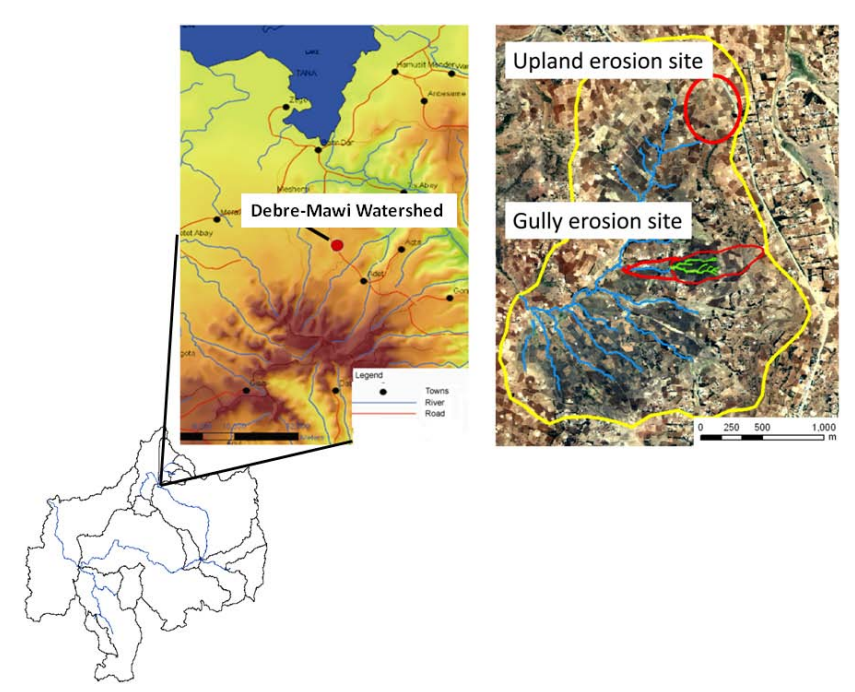

Fig. 1. Location of the Debre-Mawi watershed in the Lake Tana basin, Ethiopia, and a detailed map of the gully erosion and upland erosion sites.

the ruling class at the time displacing native landholders. This cessation of active agriculture allowed indigenous vegetation to return and cover the catchment. Following the fall of the Dreg regime, native settlers returned to the catchment in the early 1990s, and agricultural activity resumed.

\subsection{Watershed I: gully erosion site}

\subsubsection{Study site description}

This sub-watershed was selected to study gully formation. The contributing area to the gully (Fig. 1) has a total area of $17.4 \mathrm{ha}$, (1005 $\mathrm{m}$ long by $240 \mathrm{~m}$ wide at the upper end and $78 \mathrm{~m}$ at the outlet with an average width of $160 \mathrm{~m}$ ). The topography was mapped with a differential GPS (GPS 1200 Leica Geo Systems) using 1034 points (Fig. 2a). Elevation ranges from 2184 to $2300 \mathrm{~m}$ a.s.l. The gully, with two branches, is clearly visible in the images Figs. 1 and 2a. The northern gully branch (left fork referred to as gully branch A) has a relatively shallow average depth of $55 \mathrm{~cm}$, an average width of $20 \mathrm{~cm}$ at the bottom, and an average bank slope of $23^{\circ}$. The southern gully branch (referred to as gully branch B) is deeper with an average depth of $260 \mathrm{~cm}$ and a minimum width of $240 \mathrm{~cm}$. Gully banks in the southern branch are steeper with an average slope of $35^{\circ}$. The northern (A) and southern (B) gully branches join at the mid-slope position of the hillslope forming one larger, wider, and deeper gully (referred to as gully branch C). Below the junction of the two gullies, the depth decreases and the width expands, forming a local deltaic depositional zone. When the gully reaches the valley bottom area of the watershed (Figs. 1 and 2) it meets another large gully, which is advancing upslope as well. Our work focused on gullies A, B, and C, where very few soil and water conservation structures have been installed. At the current head cut locations of gullies A and $\mathrm{B}$ artificial stone bunds have been installed in an attempt to control the upward migration (Fig. 2a), otherwise there has been no attempt to mitigate gully erosion.

A geologic map was constructed (Fig. 2b) from 30 geological test pits located adjacent to the gully path and in the headwater area of the catchment. The watershed is underlain by shallow, highly weathered and fractured basalt. The fractures are highly interconnected with limited clay infillings. Surface exposures of basalt can be found on the hilltops (Fig. 2b) and in mid-slope areas on the hillsides. Weathered basalt (saprolite) can be seen in these areas as well as in the gully. An intrusive basaltic dyke is found in the centre of the southern gully branch (B) (Fig. 2b). This basaltic dyke has a general NE-SW trend, nearly perpendicular to the flow direction of the watershed. In the remaining watershed the basalt is covered with a black clay layer becoming thicker down slope. The black clay is generally underlain by brown silt loam that can be highly compacted, followed by a saprolithic layer.

The vegetation in the upper watershed $(13 \%$ of the total area) is cropland with teff or small indigenous bushes and shrubs where the top soil is too thin to sustain crop growth. An artificial rock bund exists at the boundary between the upper and middle watershed (Fig. 2a). The middle, area of the watershed $(60 \%)$ consists of crop fields principally cultivated with teff and some millet and maize. Most fields are double cropped. Livestock consisting of cows, oxen, sheep, goats, and donkeys commonly graze in the communal grazing lands particularly on the upper slope and the valley-bottom gully areas. The land is tilled three to seven times before planting, depending on the crop. The mid slope area is predominantly row crop. The lower watershed is saturated during the rainy season and covered with grass. The gullies are located in the mid slope and lower areas of the watershed.

\subsubsection{Measurements}

The historic rate of gully development was assessed through the AGERTIM method (Assessment of Gully Erosion Rates Through Interviews and Measurements, Nyssen et al., 2006) and by interpretation of air photos and satellite images. To determine the rate of gully formation the gully was visited with five key informants in four age groups (farmers of the age $20,30,40$, and 50 years). The age of the various gully segments was estimated through different questions. The key informants located different segments of the existing gully, the location of the gully head over time, and major changes in gully formation that occurred over the last three decades. The extent and location of the gully in its early stage was first estimated with the oldest informants. Information from the oldest key informant (approximately 50 yrs old) was crosschecked with information provided by younger informants. 
A
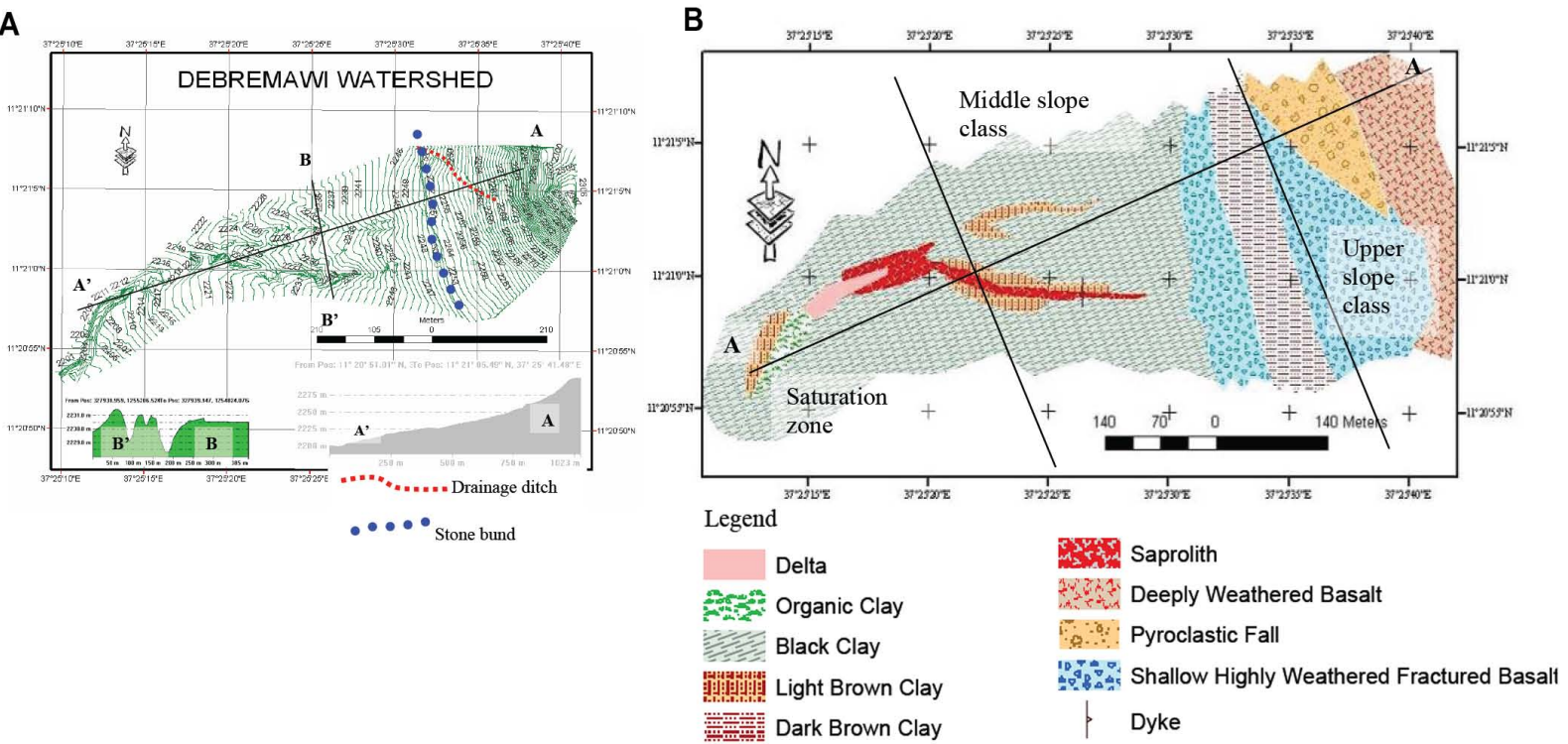

Fig. 2. (a) Contour map of the gully erosion site with gully profile transect and (b) soil map of the gully erosion site.

For 2005, the areal extent of the gullies were estimated from a QuickBird image (2005, $0.58 \mathrm{~m}$ resolution). Subsequent gully boundaries were determined before the rainy season in July 2008 (the 2007 measurement) and after the rainy season on 1 October 2008 (the 2008 measurement) by mapping the gully with a Garmin GPS with $2 \mathrm{~m}$ total (vertical and horizontal) accuracy. On 1 July and 1 October 2008, the volume and surface area of the entire gully system was estimated through measurements of width, depth, and length of cross-sectional and length profiles using a $50 \mathrm{~m}$ long measuring tape. We identified 43 gully cross-sections based on the homogeneity of the gully profile and proximity to a piezometer. For each gully cross-section, two or more widths and three or more depths were measured at locations where the cross section changed abruptly. The surface area of the entire gully system, digitized with the GPS, was crosschecked with the surface area estimated with physical measurements of gully cross-section segments.

Once the gully size was determined from the crosssectional measurements, the rates of erosion were calculated by determining the change in dimension (width, depth, length) of the different gully segments. The eroded volume, $V,\left(\mathrm{~m}^{3}\right)$ of each gully segment was calculated using the cross sectional dimensions and the distance between cross sections.

$V=\sum_{i=1}^{n} L_{i} A_{i}$

Where $L_{i}$ is the length of the considered gully segment (m) and $A_{i}$ is the representative cross sectional area of the gully segment $\left(\mathrm{m}^{2}\right)$. Long-term gully erosion rates $\left(\mathrm{tha}^{-1} \mathrm{yr}^{-1}\right)$ (RL) were calculated using the estimated current volume $(V)$ of the gully, the average bulk density (Bd) of soils occurring in the contributing area, the time span of gully development in years $(T)$ and the watershed area in hectares $(A)$.

$R_{L}=\frac{V B d}{T A}$

The soil bulk density was estimated at six locations and depths throughout the contributing area of the gully using a cylindrical core sampler with a volume of $98 \mathrm{~cm}^{3}$.

Twenty-four piezometers were installed prior to the rainy season in 2008 both in the gully's contributing area and directly inside the gully. Piezometers were constructed from PVC pipes (approximately $5 \mathrm{~cm}$ diameter) with the bottom $30 \mathrm{~cm}$ screened. Intrusion of silt and sand was prevented by wrapping filter fabric around the screened end of the wells. Both ends of the piezometer were capped. Each piezometer was installed to a maximum depth of $4.2 \mathrm{~m}$ or until the saprolithic layer was reached. In the upper watershed, depths ranged from 55 to $185 \mathrm{~cm}$ with an average depth of $115 \mathrm{~cm}$. In the mid-slope area the piezometer depth ranged from 185 to $400 \mathrm{~cm}$ with an average depth of $275 \mathrm{~cm}$, while piezometers installed in lower gully area did not reach the saprolithic layer the depths ranged from 195 to $420 \mathrm{~cm}$, and were installed just below the ground water. The exact depth of each piezometer as well as its location is given in auxiliary material. Each piezometer location was geo-referenced using a GPS unit. Measurements of water table depths in the piezometers commenced on 5 August 2008 when the water table was elevated due to the onset of the rainy season. Precipitation was measured daily using a calibrated rain gauge installed in the study catchment. Based on these measurements, the monthly rainfall totals during the study period were 8 to 10 percent greater than the corresponding mean values from the previous ten years. 


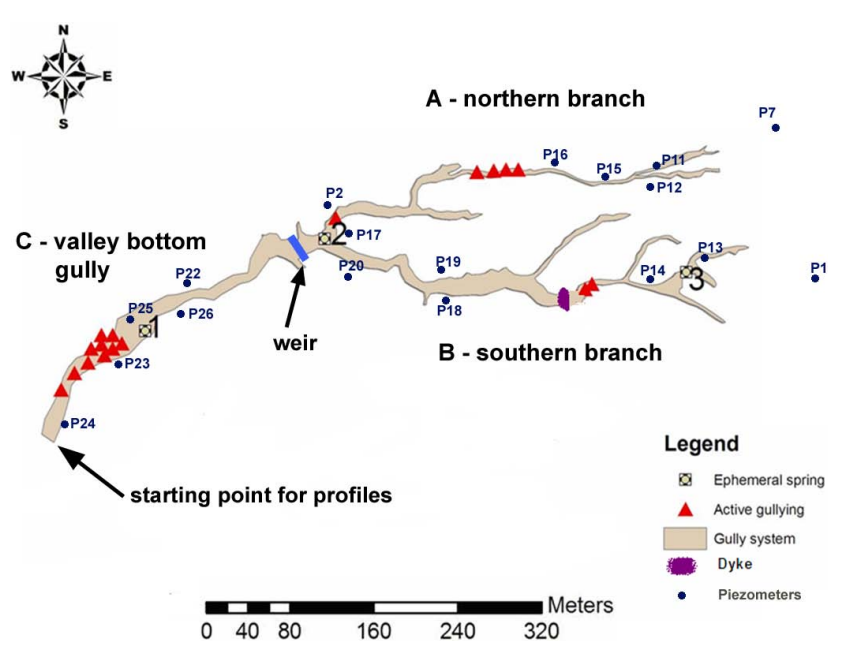

Fig. 3. The Debre-Mawi gully extent generated by handheld GPS tracking. Active erosion areas are indicated by triangles. Ephemeral springs and piezometer locations are shown as well.

\subsection{WATERSHED II: the upland erosion site}

\subsubsection{Study site description}

The second watershed was used to study upland erosion (rill and interrill erosion) processes in cultivated fields. The location of the upland site relative to the gully site is given in Fig. 1. Soils consisted of clay and clay loam and land use/land cover was similar to the gully site.

For determining rill erosion, 15 cultivated fields were selected in the contributing area, representing a cumulative area of 3.6 ha. Based on their landscape position these fields were classified into three slope positions: upslope (with a slope length of $100 \mathrm{~m}$ ), mid-slope (slope length equals $250 \mathrm{~m}$ ), and toe-slope (slope length equals $100 \mathrm{~m}$ ). A series of cross-slope transects were established with an average distance of $10 \mathrm{~m}$ between two transects; positioned one above another to minimize interference between transects (Hudson, 1993). During the rainy season, each field was visited immediately after rainfall events in July and August when the greatest rainfall amounts occur. During these visits the length, width and depth of the rills were measured along two successive transects. The length of a rill was measured from its upslope starting point down to where the eroded soil was deposited. Widths were measured at several points along a rill and averaged over the rill length (Herweg, 1996). From these measurements, different magnitudes of rill erosion were determined, including rill volumes, rates of erosion, density of rills, area impacted by the rills, and the percentage of area covered by the rills in relation to the total area of surveyed fields (Herweg, 1996; Hagmann, 1996; Bewket and Sterk, 2003). The rill magnitudes were calculated using the following equations:

$X=\frac{\sum\left(L_{i} W_{i} D_{i}\right) N_{i}}{10000 A}$
$\mathrm{AAD}=\frac{\sum\left(L_{i} W_{i}\right) N_{i}}{100 A}$

$D=\frac{\sum\left(L_{i}\right) N_{i}}{A}$

Where $X$ is the volume of rills $\left(\mathrm{m}^{3} \mathrm{ha}^{-1}\right), L_{i}$ is the length of a rill (m), $W_{i}$ is the width of a rill $(\mathrm{cm}), D_{i}$ is the depth of a rill $(\mathrm{cm})$, AAD is the area of actual damage affected by rill erosion $\left(\mathrm{m}^{2} \mathrm{ha}^{-1}\right), D$ is the density of rills $\left(\mathrm{m}^{2} \mathrm{ha}^{-1}\right)$, $A$ is the field area (ha), and $N$ is the number of rills. $X$ is equivalent to the volume of soil lost due to the formation of rills. The eroded soil volume was also expressed in terms of weight of eroded soil by multiplying $X$ with the soil bulk density of each of the 15 fields (Hagmann, 1996).

The percentage crop canopy coverage was estimated whenever rill measurements were taken. The spatial variation of rill erosion was analyzed by assessing the distribution of the rate of soil erosion, rill density, and areas of actual damage across the surveyed fields with respect to their relative topographic positions (i.e. upslope, mid-slope and down-slope) and crop type. Deposition was estimated by the decrease in rill dimensions, (depths and lengths) at the end of the rainy season. In addition, deposition and interrill erosion in the fields were also estimated using the Universal Soil Loss Equation (USLE) with parameters derived for the Ethiopian Highlands by Hurni (1988).

\section{Results}

\subsection{Long term evolution of gully development in Debre-Mawi}

Debre-Mawi watershed has many active, permanent gullies. We selected one of the more active gullies (Fig. 1) with a contributing area of $17.4 \mathrm{ha}$. According to farmer interviews, the gully began actively incising in the late 1980s, which corresponds to the time when the watershed was re-settled and the indigenous vegetation on the hillsides was cleared and converted to agricultural land. According to the respondents, in the early 1980's, the valley bottom of the study area was marshy, and grasses were grown all year long. There were three ephemeral springs located in the valley bottom in the 1980's (SPRINGS 1, 2, and 3, Fig. 3). Respondents agreed on the incision location and confirmed that the locations of the incisions were related to three ephemeral springs in the valley. According to the oldest respondent the lowest spring, SPRING1, had flow all year long and was used to fill a pond. According to the farmer, the time when the pond began to dry up coincided with the incision of the gully in the valley bottom. According to the local informants the marshy area around the second spring (SPRING 2) changed into a branched gully with a northern and a southern gully branch following re-settlement of the watershed. 


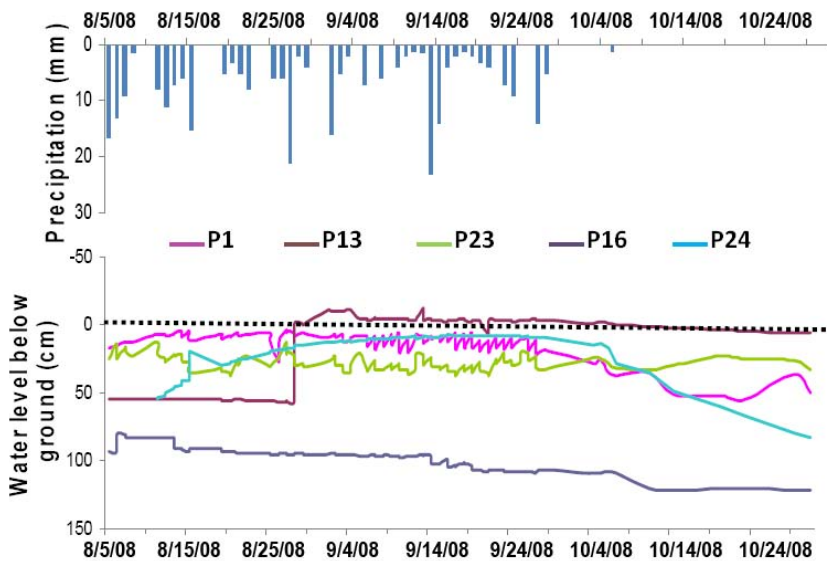

Fig. 4. Water table elevations for selected wells in and around the active gully section. Precipitation during the period is also shown.

The third spring (SPRING 3), located near the head cut areas of the southern gully branch is still actively eroding into the hillside as indicated by newly developed, ephemeral side branches (Fig. 3).

\subsection{Gully development processes}

The Debre-Mawi gully is very active in a few areas as indicated by the red triangles in Fig. 3. Below we discuss the gullying mechanisms for each of the gully sections. We will show that in all cases of active gullying the water table is above the gully bottom.

Figure 4 shows the depth of the water table for several piezometers near the gully. Piezometers P23 and P24 are located in the valley bottom, P13 and P1 in the southern gully branch (branch B) and P16 in the northern gully branch (branch A). The abrupt rise of the water level in P13 on August 28 was due to the increase in rainfall. After the rainy season water levels in the piezometers declined slowly with the exception of P24, which declined very rapidly. This piezometer is located near the newly formed head cutting zone in gully branch B and shows a faster drop in the water table than the other piezometers.

\subsection{Valley bottom gully (branch $\mathrm{C}$ )}

The depths (Fig. 5a) and the corresponding widths (Fig. 5b) of the gully in the valley bottom (branch C) were estimated before (2007) and after (2008) the rainy season as a function of the distance from the valley bottom. The average water table depth for the piezometers closest to the gully bottom (from bottom to top P24, P23, P22 and P26 and P17) are shown and indicate that the valley bottom is saturated close to the surface while further upstream the water table falls below the gully bottom. During the 2008 rainy season the gully was actively incising, further head cutting past the $187 \mathrm{~m}$ mark (from the gully outlet, Fig. 5a) and widened up to $20 \mathrm{~m}$ in

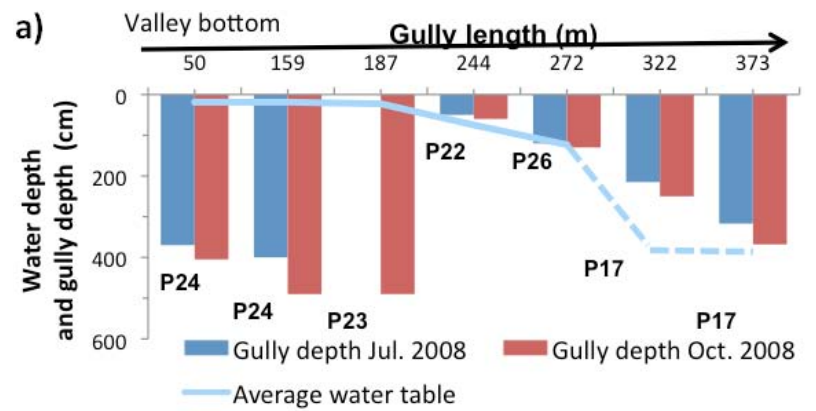

b)

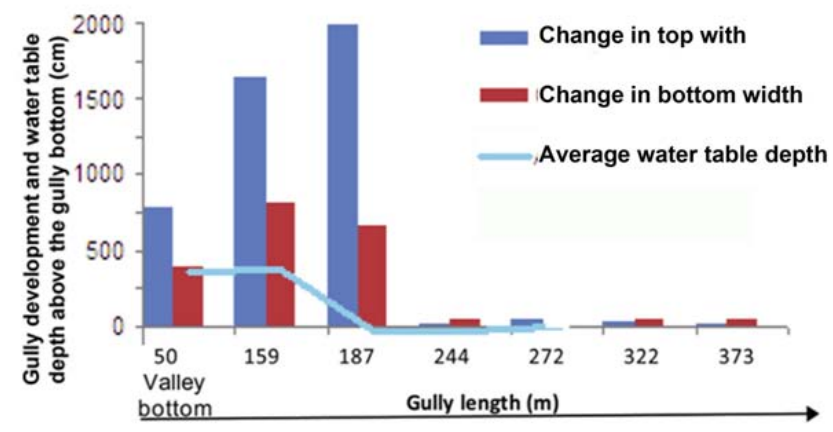

Fig. 5. (a) Average water table depth and gully depths before and after the 2008 rainy season for the main stem (gully C) using the soil surface as a reference elevation point. Note that piezometers p17 and p24 were adjacent to two gully cross-sections and (b) change in top and bottom width of the gully and average water table depth above the gully bottom.

top width (Fig. 5b) where the water table was near the surface (approximately $4 \mathrm{~m}$ above the gully bottom, Fig. 5a). Under static conditions the pore water pressure near the head cut point is $4 \mathrm{~m}$, which might be sufficient to cause slumping of the gully walls (Fig. 6).

The piezometers P24 and P26 at 244 and $272 \mathrm{~m}$ from the junction, respectively show that while the water table is near the surface the gully has not incised yet (Fig. 5a). If our current theories on gully formation and advance are right, then, over the next few rainy seasons, it is likely that the gully head will rapidly incise and migrate uphill in these saturated soils. At sites 323 and $372 \mathrm{~m}$ from the bottom, the water table is below the bottom of the P17 piezometer and thus below the bottom of the gully. Here the gully is relatively stable despite its $3 \mathrm{~m}$ depth, and although there was still some erosion (e.g. Fig. 5), the rate is small compared to adjacent areas with elevated water table levels.

\subsection{North gully (branch A)}

The active gully erosion process in the northern gully (branch A) is driven by similar ground water dynamics as found in the valley bottom (Fig. 7). The change in gully depth and bottom and top width during the 2008 rainy season is depicted in Fig. 7a, and b. Notice that we do not show the gully depth in 

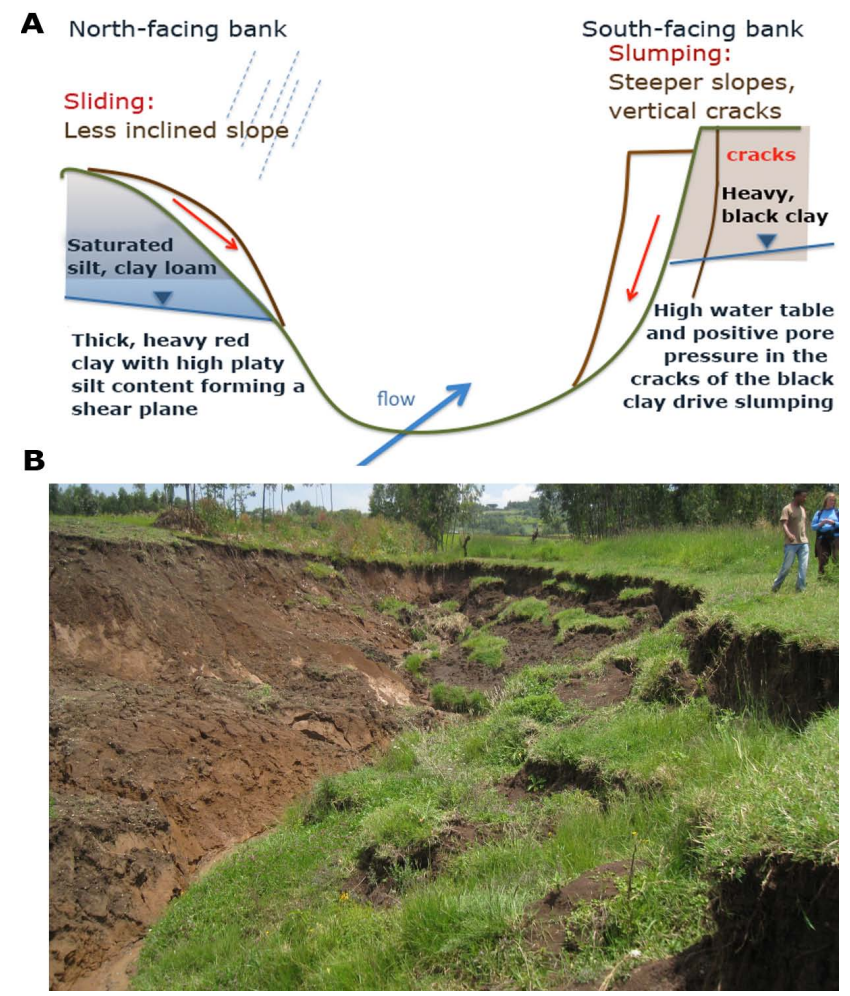

Fig. 6. (a) Schematic diagram of gully erosion processes and (b) example of gully bank failures.

October 2008, as the erosion was the result of gully widening (e.g., Fig. 7b). The water table height above the gully bottom was obtained by subtracting the water table depth from the gully depth. Positive numbers indicate that the water table is above the bottom of the gully and negative numbers indicate it is below the gully bottom. Although the relationship is not as dramatic as in the main gully branch (branch C) (Fig. 5), the general trend is quite similar. Where the water table is approximately $2 \mathrm{~m}$ below the valley bottom (at $130 \mathrm{~m}$ from the junction of branches A and C) the gully is stable. However, at the sites 201 and $231 \mathrm{~m}$ above the junction the water table is $75 \mathrm{~cm}$ above the gully bottom. In this area the gully dimensions increase most dramatically (Fig. 7b).

\subsection{South gully (branch B)}

Widening in the southern gully branch is influenced by the presence of saprolite close to soil surface. The basalt and saprolite outcrop (referred to as dyke in figures) are shown in Fig. 8a. Figure $8 \mathrm{~b}$ shows that the most active gully formation occurred at $263 \mathrm{~m}$ from the junction with branch B just uphill from the dyke where the water table was approximately $3 \mathrm{~m}$ above the gully bottom (Fig. 8 b). Similar to gully branch A, gully B development was the result of gully widening (e.g., Fig. 8b). At this site, the saprolite outcrop acts as a dam for lateral ground water flow, and ground wa-
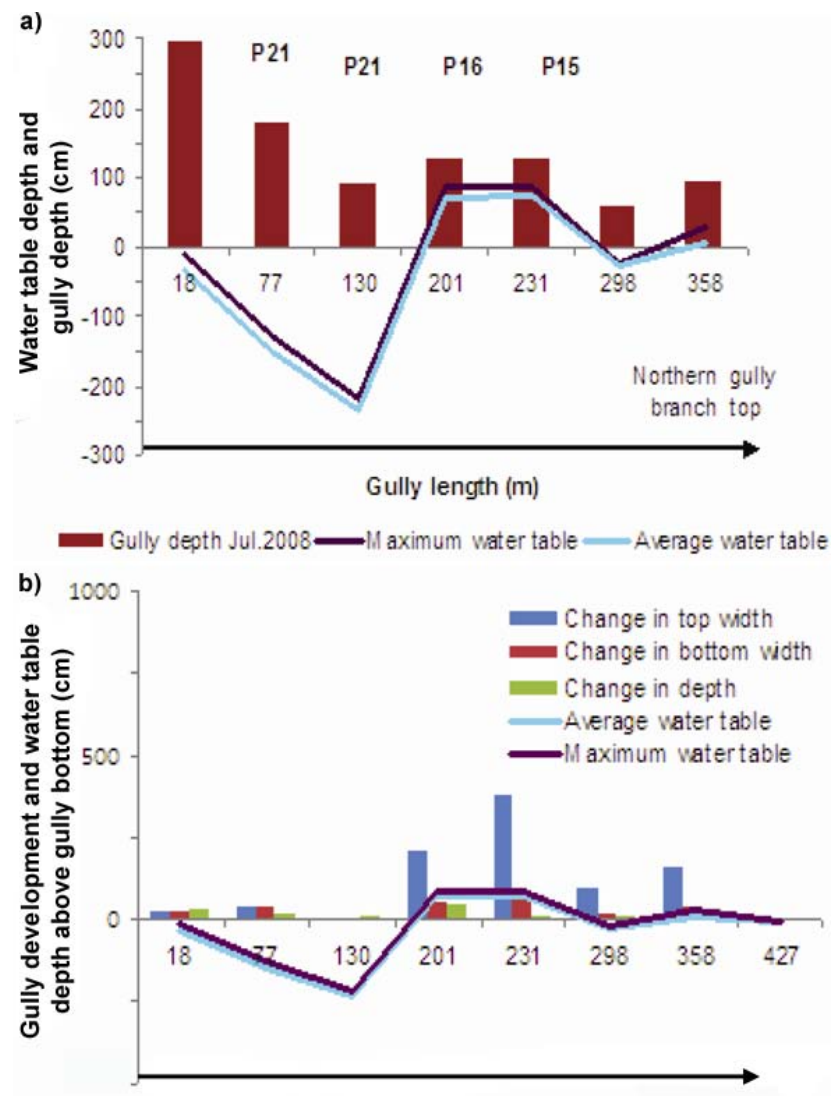

Gully Length (m)

Fig. 7. (a) Gully dimensions before and after the 2008 rainy season for the northern gully branch A (note the gully bottom is the reference elevation) and (b) depths and average ground water table and change in top and bottom width and depth of the gully.

ter remains perched above the gully bottom. Downhill from the dyke at the site $115 \mathrm{~m}$ from the junction the water table below the gully bottom, likely a result of the little flow contribution from upslope (Fig. 8a) because the dyke prevents lateral flows from advancing. Note also that there was no widening or deepening of the gully at this location (Fig. 8b). Unlike gully branch A and valley bottom gully (branch C) where the water table stays above the gully bottom causing a collapse of the walls, there is no widening in the gully in the section 300 to $400 \mathrm{~m}$ from the junction with branch A (Fig. $8 \mathrm{a}$ and b) despite the elevated water table (1-2 $\mathrm{m}$ above the gully bottom). Here the water is ponded on the saprolite layer and seeps through the saprolite to the gully. Thus, based on our observations in the gully, it appears that the rock seems to provide a stable foundation for the bank, thus preventing collapse. 
Table 1. Gully erosion losses calculated with Eqs. (1) and (2) for the sum of gullies A and B and gully C. Erosion rates calculated from the gullies are then distributed uniformly over the contributing area.

\begin{tabular}{lccc}
\hline Gully location & \multicolumn{3}{c}{ Soil loss } \\
\cline { 2 - 4 } & $\begin{array}{c}1981-2007 \\
\left(\mathrm{t} \mathrm{ha}^{-1} \mathrm{yr}^{-1}\right)\end{array}$ & $\begin{array}{c}2007-2008 \\
\left(\mathrm{t} \mathrm{ha}^{-1} \mathrm{yr}^{-1}\right)\end{array}$ & $\begin{array}{c}2007-2008 \\
\left(\mathrm{~cm} \mathrm{yr}^{-1}\right)\end{array}$ \\
\hline Branches (Gullies A and B)* & 17.5 & 128 & 1 \\
Main stem (Gully C) & 13.2 & 402 & 3 \\
Total & 30.7 & 530 & 4 \\
\hline
\end{tabular}

* Note that the calculated erosion rates for gullies A and B were nearly identical, and are thus presented in aggregates.

\subsection{Estimating gully erosion rates}

Erosion rates for the main gully (branch $\mathrm{C}$ ) and two gully branches (A and $\mathrm{B}$ ) are given in Table 1. The increase in the erosion rate of the main gully between 2007 and 2008 can be explained by recent widening and deepening of the gully at the lower end (Fig. 2). Estimations of the areal extent of the gully in 2005 from the QuickBird image and 2008 before and after the rainy season showed that from 2005 to 2007 , the gully system increased from 0.65 ha to $1.0 \mathrm{ha}$, a $43 \%$ increase in area. During 2008, it increased by $60 \%$ to cover 1.43 ha at the end of the rainy season in 2008.

Based on the estimates of the gully size from the crosssectional measurements and an average soil bulk density $\left(1.24 \mathrm{~kg} \mathrm{~m}^{-3}\right)$ the mean gully erosion rate since the incision period from 1981 to 2008 was equivalent to $31 \mathrm{tha}^{-1}$ per year in the contributing watershed. The gully erosion rate has accelerated significantly since 2007 . After the 2008 rainy season the erosion rate was estimated at $530 \mathrm{t} \mathrm{ha}^{-1}$ (Table 1), which is equivalent to nearly $4 \mathrm{~cm}$ of soil from the contributing watershed. These values are extreme for the region compared to the results from other studies (e.g., Daba et al., 2003 and Nyssen et al., 2006), but little work has explored erosion rates from active gullies.

\subsection{Upland erosion}

We compare the gully erosion estimates calculated above, to measurement of rill and interrill made on adjacent fields. The average upland erosion measured from the 15 agricultural fields is $27 \mathrm{tha}^{-1}$ during the 2008 rainy season. The erosion plots located at toe slope areas had significantly greater soil loss $\left(34 \mathrm{tha}^{-1}\right)$ and a greater area impacted by rills $\left(884 \mathrm{~m}^{2}\right)$ than either the plots in the mid or upper slope areas (Table 2). Higher erosion rates from toe slope areas are not uncommon, as these areas tend to receive greater flow from upslope areas, and saturate more frequently, resulting in greater runoff loses, and hence more erosion (Easton et al., 2010). Erosion rates $\left(8-34 \mathrm{tha}^{-1}\right)$ from all slope locations were several orders of magnitude lower than the gully erosion rates in 2008. The average soil loss for each observation date is shown for

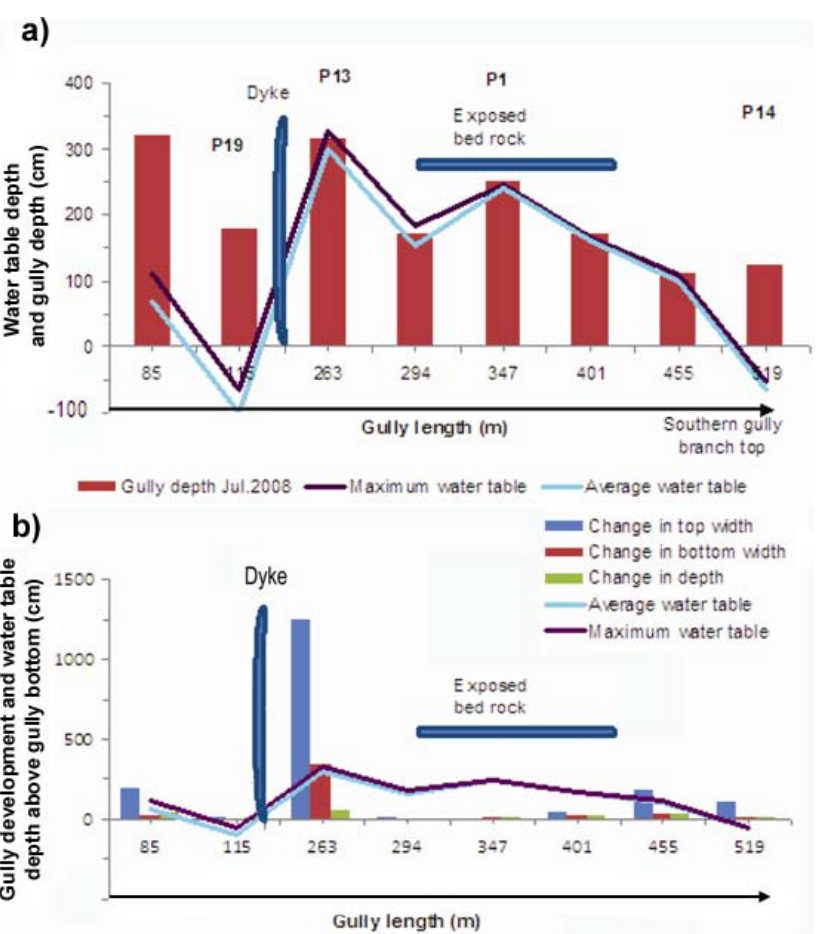

Fig. 8. (a) Gully dimensions before and after the 2008 rainy season for the southern gully, branch B (note the gully bottom is the reference elevation) and (b) average ground water table depths and change in top and bottom width and depth of the gully.

the various crops in Table 3. The teff fields had the greatest density of rills and generally the greatest erosion rates (Table 3), which correspond with the reduced crop coverage following planting (Table 3). Teff fields are planted in the middle of the rainy season when higher intensity rains generally occur and thus there is more area with little or no ground cover. Later in the growing season, once plant cover was established tef actually had greater sediment depositions rates than the other crops due to the dense root and ground cover slowing runoff and allowing sediment to settle out. In late August, the rills degrade (or collapse, filling in) resulting in 
Table 2. Soil loss, area affected, rill density, and slope percent for the three different slope positions. Means with different letter within a column are significantly different based on a paired t-test at $\alpha=0.05$.

\begin{tabular}{lccccc}
\hline Slope Position & \multicolumn{3}{c}{ Soil Erosion Effect } & & Erosion Factor \\
\cline { 2 - 3 } \cline { 6 - 6 } & $\begin{array}{c}\text { Soil loss } \\
\left(\mathrm{tha}^{-1}\right)\end{array}$ & $\begin{array}{c}\text { Area of actual damage } \\
\left(\mathrm{m}^{2} \mathrm{ha}^{-1}\right)\end{array}$ & $\begin{array}{c}\text { Rill density } \\
\left(\mathrm{m}^{2} \mathrm{ha}^{-1}\right)\end{array}$ & $\begin{array}{c}\text { Slope } \\
(\%)\end{array}$ \\
\hline Down slope & $34^{\mathrm{a}^{\mathrm{*}}}$ & $884^{\mathrm{a}}$ & $4946^{\mathrm{a}}$ & & $14^{\mathrm{a}}$ \\
Mid-slope & $23^{\mathrm{b}}$ & $662^{\mathrm{b}}$ & $2860^{\mathrm{b}}$ & \\
Upslope & $8^{\mathrm{c}}$ & $256^{\mathrm{c}}$ & $1029^{\mathrm{c}}$ & & $9^{\mathrm{b}}$ \\
\hline
\end{tabular}

* Means followed by different letters (a, b, c) with in columns are significantly different at $\alpha=0.05$.

Table 3. Soil loss, percent plant cover on days of observation, and the 5 day antecedent precipitation for upland erosion measurements, $\mathrm{mz}=$ maize $\mathrm{wh}=$ wheat $\mathrm{mt}=$ millet.

\begin{tabular}{|c|c|c|c|c|c|c|c|c|c|}
\hline \multirow[t]{2}{*}{ Date } & \multirow{2}{*}{$\begin{array}{l}\text { Precipitation } \\
\left(\mathrm{mm} 5 \mathrm{~d}^{-1}\right)\end{array}$} & \multicolumn{4}{|c|}{ Rate of Soil Loss ( $\mathrm{tha}^{-1}$ ) } & \multicolumn{4}{|c|}{ Crop Coverage (\%) } \\
\hline & & maize & wheat & millet & tef & $\mathrm{mz}$ & wh & $\mathrm{mt}$ & tef \\
\hline $7 / 11 / 2008$ & 51 & 4.9 & 0.9 & 6.9 & 7.3 & 26 & 3 & 10 & 0 \\
\hline $7 / 18 / 2008$ & 75 & 8.3 & 0.6 & -1.4 & 6.8 & 36 & 10 & 25 & 1 \\
\hline $7 / 22 / 2008$ & 69 & 1.4 & 4.9 & -2.0 & 4.2 & 40 & 25 & 30 & 5 \\
\hline $7 / 29 / 2008$ & 55 & 0.1 & 0.5 & 0.8 & 2.2 & 46 & 53 & 55 & 15 \\
\hline $8 / 1 / 2008$ & 57 & -1.0 & 0.6 & -0.5 & 2.4 & 50 & 55 & 55 & 17 \\
\hline $8 / 12 / 2008$ & 34 & -3.0 & -0.7 & -3.8 & -7.0 & 60 & 70 & 70 & 40 \\
\hline $8 / 27 / 2008$ & 52 & -1.1 & -0.7 & & -0.6 & 75 & 85 & 90 & 75 \\
\hline
\end{tabular}

negative soil loss (e.g., deposition) on some fields (Table 3). The erosion is greatest at the end of June when the soil is loose, dry, and easily erodible (Bewket and Sterk, 2003). After the onset of the rainy season, the soils wet up and plant cover is established, and erosion rates decrease across all crop types (Table 3).

The rill erosion measurements taken in the field do not consider soil loss from between the rills (i.e., interrill erosion) and thus likely underestimates the actual erosion rate. According to Zachar (1982), considering only rill erosion generally results in underestimates of 10 to $30 \%$ of the actual soil loss. Govers (1991) also reported that interrill erosion can contribute more than $30 \%$ to the total soil loss in fields, where rills are present. Similarly, Bewket and Sterk (2003) assumed that $30 \%$ of the actual soil loss is contributed by interrill erosion. In this study, we therefore assumed that the measured rill erosion rates underestimated soil loss by $25 \%$ $\left(9 \mathrm{tha}^{-1}\right)$, making the annual average actual soil loss rates approximately $36 \mathrm{tha}^{-1}$.

\section{Discussion}

Poesen et al. (2003) list gully erosion rates for 60 different locations around the globe. The gully erosion rates range from a low of $0.1 \mathrm{tha}^{-1} \mathrm{yr}^{-1}$ in New South Wales, Australia to a maximum of $65 \mathrm{tha}^{-1} \mathrm{yr}^{-1}$ in Spain. The percentage of gully soil loss as a percentage of total soil loss from a watershed range from $10 \%$ in Belgium to $94 \%$ in Lesotho. Thus, the historic gully erosion rates $\left(30.7 \mathrm{t} \mathrm{ha}^{-1} \mathrm{yr}^{-1}\right)$ estimated in the Debre-Mawi watershed, which represent $64 \%$ of the total soil loss (if we assume that the rill and interrill erosion rates measured in 2008 are representative of historic averages) (Table 1), falls in the midrange of the values listed by Poesen et al. (2003). The gully erosion rates for 20072008 of $530 \mathrm{tha}^{-1} \mathrm{yr}^{-1}$ represent $97 \%$ of the total soil loss, which is far greater than any of the observed gully erosion rates reported by Poesen et al. (2003).

The gully erosion rates measured in this study, while indeed high, might not be representative of long term, catchment wide erosion rates. For instance, many of the rates reported by Poesen et al. (2003) represent long term averages, and thus if these gullies stabilize in the near future the erosion rates will fall, and might in fact act as depositional areas for new sediments and thus the erosion rates, presented as long term averages, will be lower.

For both the upland erosion and the gully erosion there is a clear relationship between moisture content and the rate of erosion. In the gully, where the water table is close to the gully bottom, gully erosion occurs by the sliding of the gully walls (both at the head cutting end and from the sides) 
into the bottom of the gully. Slumping occurs, because the pore water pressure above the gully bottom pushes the soil out when soils are saturated and the pore water pressure is greater than the soil strength. Thus, the elevated water table causes the rapid upslope migration of the gully head (Fig. 3). When the water table is below the gully bottom the soil is unsaturated and maintains some degree of cohesive strength. If the gully widens when the soil is unsaturated, it is caused by overland flow entering the gully, but this occurs at much lower rates than when the soil is saturated (Fig. 7).

It is of interest to examine why the active gully in DebreMawi continues to expand. According to a formal and informal survey carried out in the watershed, gullying began in the late 1980's following the removal of indigenous vegetation, leading to an increase of surface and subsurface runoff from the hillside to the valley bottoms. This increased flow then increased saturation at the bottom of the slope and formed a small disturbance (either natural or perhaps from grazing animals) and a small gully forms. Once these initial gullies form they migrate rapidly upslope beyond the control of the local people. Thus our results agree in part with those of Mogus and Holden (2008) who indicated that gully formation is human induced such as when forests are replaced by agricultural land, the evaporative term in the water balance becomes smaller, making the soils wetter and sometimes saturated. These saturated soils lack cohesive strength and thus a gully can more easily form.

Many studies on gully erosion have reported that gullying initiation can be worsened by a dry period (Nyssen et al., 2006). Often during a dry period, particularly in crack prone soil such as the vertisols, common to the Highlands, preferential flow paths can form. Preferential flow paths result in a positive pore pressure in unsaturated soils (Collison and Simon, 2001). Thus, locations that were saturated during wet periods dry out and crack during dry periods, often to considerable depth. When rainfall resumes water infiltrates in these cracks and can cause a positive pore water pressure that can initiate gully formation. Once the gully is established and the ground water is drained the soil becomes unsaturated, regains its strength in the surrounding areas, and the gully stabilizes. Gully formation stops when the gully has back cut to a location where the slope steepness is great enough to prevent a water table from becoming elevated above the gully bottom for extend periods.

\section{Conclusions}

Comparing the gully and upland erosion rates in the DebreMawi watershed, indicates that the soil loss rate of the gully system is approximately 20 times higher than the erosion rates for areas dominated by rill and interrill erosion. While significantly lower than gully erosion, rill erosion is still nearly four times greater than the generally accepted soil loss rate for the region and thus cannot be ignored in terms of agricultural productivity and soil fertility. However, if reservoir siltation and water quality of Lake Tana and the Blue Nile are the primary impetus for soil conservation, gully erosion has far greater consequences.

In terms of gully erosion control mechanisms, the most effective would appear to be dewatering of the soil in the areas directly connected to the gully system. This can be accomplished with drain tiles which, in theory, are practical. However, installation of drain tiles under Ethiopian conditions may be infeasible due to the relatively high costs and lack of mechanized equipment for installation. A management practice that is relatively low cost and easily implemented in the Highlands would be to plant eucalyptus trees on locations where the original forest was removed, which would increase evapotranspiration and lower the water table (Lane et al., 2004). Once started, gully formation can be stopped (or reduced) by stabilizing the gully as soon as it is incised. This requires continuous attention of the farmers and soil and water specialists.

\section{References}

Beshah, T.: Understanding farmers: explaining soil and water conservation in Konso, Wolaita and Wello, Ethiopia, Tropical Resource Management Papers, 41, p. 245, 2003.

Bewket W. and Sterk G.: Assessment of soil erosion in cultivated fields using a survey methodology for rills in the Chemoga watershed, Ethiopia, Agriculture, Ecosystems and Environment, 97, 81-93, 2003.

Bewket, W. and Sterk, G.: Dynamics in land cover and its effect on stream flow in the Chemoga watershed, Blue Nile basin, Ethiopia, Hydrol. Process., 19, 445-458, 2005.

Carey, B.: Gully ersosion. Facts Natural Resources and Water. Managing Queensland natural resources for today and tomorrow, Natural Resource Science, www.nrw.qld.gov.au, 2006.

Carnicelli, S., Benvenuti, M., Ferrari, G., and Sagri, M.: Dynamics and driving factors of late Holocene gullying in the Main Ethiopian Rift (MER) Geomorphology, 103, 541-554, 2009.

Collison, A. and Simon, A.: Modeling gully head-cut recession processes in Loess deposits, 87-90 in Soil Erosion Research for the 21st Century, Proc. Int. Symp. (3-5 January 2001, Honolulu, HI, USA), edited by: Ascough II, J. C. and Flanagan, D. C., St. Joseph, MI, ASAE, 701P0007, 2001.

Daba, S., Rieger, W., and Strauss, P.: Assessment of gully erosion in eastern Ethiopia using photogrammetric techniques, Catena, 50, 273-291, 2003.

Easton, Z. M., Fuka, D. R., White, E. D., Collick, A. S., Biruk Ashagre, B., McCartney, M., Awulachew, S. B., Ahmed, A. A., and Steenhuis, T. S.: A multi basin SWAT model analysis of runoff and sedimentation in the Blue Nile, Ethiopia, Hydrol. Earth Syst. Sci., 14, 1827-1841, doi:10.5194/hess-14-1827-2010, 2010.

Fox, G. A., Wilson, G. V., Simon, A., Langendoen, E. J., Akay, O., and Fuchs, J. W.: Measuring stream bank erosion due to ground water seepage: correlation to bank pore water pressure, precipitation and stream stage. Earth Surface Processes and Landforms, 32(10), 1558-1573, 2007. 
Fox, G. A. and Wilson G. V.: The Role of Subsurface Flow in Hillslope and Stream Bank Erosion: A Review, Soil Sci. Soc. Am. J., 74, 717-733, 2010.

Govers, G.: Rill erosion on arable land in central Belgium: Rates, controls, and predictability, Catena, 18, 133-155, 1991.

Hagberg, T. D.: Relationships between hydrology, vegetation, and gullies in montane meadows of the Sierra Nevada, M. S. Thesis, Humboldt State University, Arcata, California, 177 pp., 1995.

Hagmann, J.: Mechanical soil conservation with contour ridges: cure for, or cause of, rill erosion?, Land Degradation and Development, 7, 145-160, 1996.

Herweg, K.: Field manual for assessment of current erosion damage. Soil conservation research programme (SCRP), Ethiopia and centre for development and environment (CDE), University of Berne, Switzerland, 1996.

Herweg, K. and Ludi E.: The performance of selected soil and water conservation measures, case studies from Ethiopia and Eritrea, Catena, 36, 99-114, 1999.

Hoben, A.: Paradigms and Politics: The Cultural Construction of Environmental Policy in Ethiopia, World Development, 23(6), 1007-1021, 1995.

Hudson, N. W.: Field measurement of soil erosion and runoff. Food and Agricultural Organization (FAO) of the United Nations Ampthil, UK, 1993.

Hurni, H.: Degradation and Conservation of the Resources in the Ethiopian highlands. Mountain Research and Development, 8, 123-130, 1988.

Hurni, H., Kebede, T., and Zeleke, G.: Implications of Changes in Population, Land Use and Land Management for surface runoff in the upper basin area of Ethiopia, Mountain Research and Development, 25(2), 147-154, 2005.

Lane, P. N. J., Morris, J., and Ningnan, Z.: Water balance of tropical Eucalyptus plantations in southeast China, Agricultural and Forest, 124, 253-267, 2004.

Moges, A. and Holden, N. M.: Estimating the rate and consequences of gully development, a case study of umbulo catchment in southern Ethiopia, Land Degradation and Development, 19, 574-586, 2008.
Nyssen, J., Poesen, J., Moeyersons, J., Deckers, J., Mitiku, H., and Andreas, L.: Human impact on the environment in the Ethiopian and Eritrean highlands. A state of the art Earth-Science Reviews, 64, 273-320, 2004.

Nyssen, J., Poesen, J., Veyret-Picot, M., Moeyersons, J., Haile , M., Deckers J., Dewit, J., Naudts, J., Teka, K., and Govers, G.: Assessment of gully erosion rates through interviews and measurements: a case study from northern Ethiopia. Earth Surface Processes and Landforms, 31, 167-185, 2006.

Okagbue, C. O. and Uma, K. O.: Performance of gully erosion control measures in southeastern Nigeria. IAHS Publications, 167, 163-172, 1987.

Poesen, J., Nachtergaele, J., Verstraeten, G., and Valentin, C.: Gully erosion and environmental change: importance and research needs, Catena., 50, 91-133, 2003.

Poesen, J., Vandekerckhove, L., Nachtergaele, J., Oostwoud Wijdenes, D., Verstraeten, and G., van Wesemael, B.: Gully erosion in dryland environments, in: Dryland Rivers: Hydrology and Geomorphology of Semi-Arid Channels, edited by: Bull, L. J. and Kirkby, M. J.,Wiley, Chichester, UK, 229-262, 2002.

Shiferaw, B. and Holden, S.: Resource degradation and adoption of land conservation technologies in the Ethiopian highlands: a case study in Andit Tid, North Shewa. Agric. Econ., 18, 233247, 1998.

Soil Science Society of America: Glossary of Soil Science Terms. Soil Science Society of America, Madison, WI, https://www. soils.org/publications/soils-glossary last access: 2 July 1010.

Tamene L. and Vlek, P. L. G.: Assessing the potential of changing land use for reducing soil erosion and sediment yield of catchments: a case study in the highlands of northern Ethiopia Soil Use and Management, March 2007, 23, 82-91, 2007.

Wilson, G. V., Shields F. D., Jr, Binginer, R. L., Reid-Rhoades, P., DiCarlo, D. A., and Dabney, S. M.: Conservation practices and gully erosion contributions in the Topashaw Canal watershed, Journal of Soil and Water Conservation, 63(6), 420-429, doi:10.2489/jswc.63.6.420, 2008.

Zancher, D.: Soil Erosion, Developments in Soil Sciences, Elsevier, Amsterdam, 1982. 